\title{
A comparison of biological methods with rats for determining the nutritive value of proteins
}

\author{
BY KATHLEEN M. HENRY \\ National Institute for Research in Dairying, Shinfield, Reading \\ (Received ${ }_{5}$ September r964-Accepted 3 November 1964)
}

The old-established growth method of Osborne, Mendel \& Ferry (19r9) for determining the protein efficiency ratio (PER) of protein sources has recently been suggested both in Canada (Chapman, Castillo \& Campbell, 1959) and the USA (Derse, 1960) as a routine method for assessing the nutritive value of proteins. Njaa (1963) in a detailed study of the nitrogen balance sheet method for measurement of biological value (Bv) (Mitchell, 1923-4a) considers that it and the growth method (PER) are preferable to other biological methods of protein assessment and that the former is more satisfactory than the latter in short-term experiments as it gives both more detailed information and more consistent results. Bigwood (I964) has also recommended $\mathrm{BV}$ as the most satisfactory estimate of protein quality. We have already reported (Henry \& Toothill, I962) a good correlation between the $\mathrm{N}$ balance sheet and the body-water (Miller \& Bender, 1955) methods in assessing the nutritive value of a series of thirty-five protein sources. Sufficient quantities of twenty-four of them were available for the determination of their PER and the results are now reported for values obtained at an $8 \%$ level of protein intake.

Several methods of protein assessment are compared and the definitions of the terms used are:

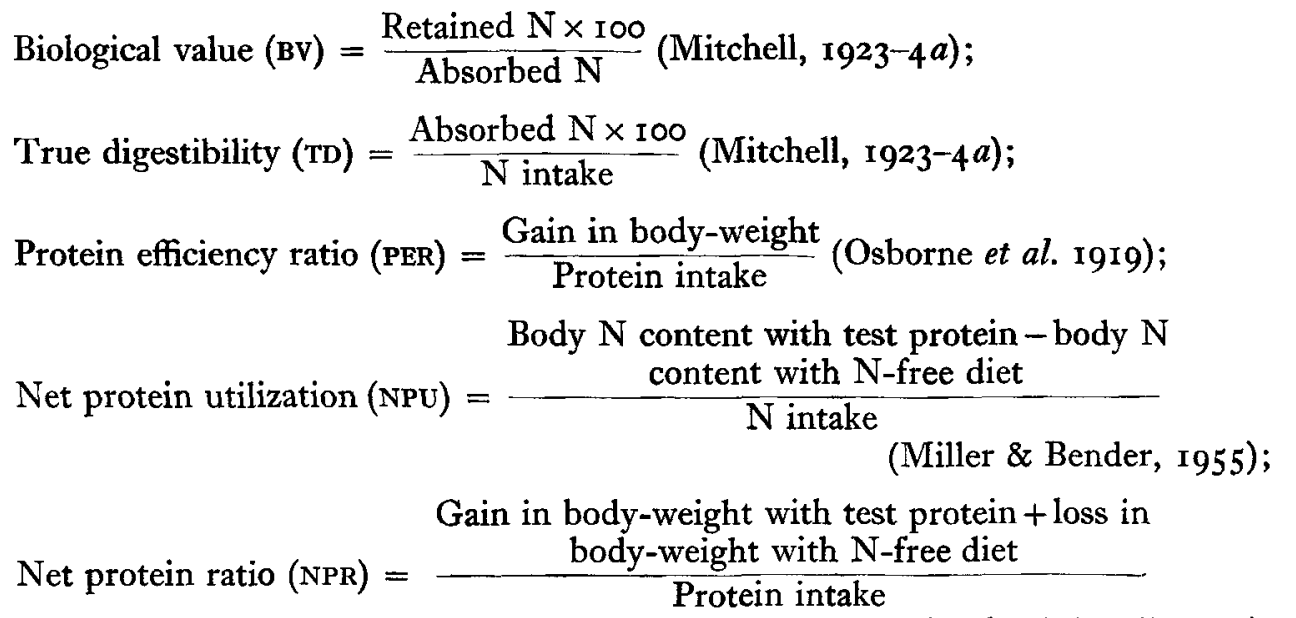

(Bender \& Doell, r957).

It is now usual to determine PER at a single (8-10\%) level of protein intake. In the original method, however, Osborne et al. (1919) determined the PER of a protein at 
several levels and accepted the peak value. Henry \& Kon (1957) reported that the Bvs of egg proteins and of casein did not change when the level of protein intake was increased from 4 to $8 \%$ but decreased progressively when the dietary protein level was increased to 12 and $16 \%$. Results of a similar test with a poor-quality protein, wheat gluten, are now reported together with values for PER and for net protein utilization (NPU), calculated from body-water measurements (Miller \& Bender, 1955), for these three protein sources determined at $4-20 \%$ levels of intake.

We have found (Henry, Cormack \& Kosterlitz, i961 and unpublished) that for cortisone-treated rats the $\mathrm{BV}$ of proteins is reduced but that their nutritive value as determined from $\mathrm{N}$ deposition in the liver is unchanged. It was, therefore, of interest to see in what way cortisone would affect the NPU, determined from body-water measurements, of those proteins already studied.

Working with several species of animal, a number of workers have reported higher $N$ retentions when measured in balance experiments than by carcass analysis (cf. Butterworth, 1962). In this laboratory (Henry \& Toothill, 1962) we have found that the $\mathrm{N}$ content of the carcasses of rats given experimental diets is slightly underestimated when it is calculated from equations relating body water to body $\mathrm{N}$ and derived from values for rats given our stock diet. For these reasons an experiment was arranged in which $\mathrm{N}$ retention from a ' $\mathrm{N}$-free' diet and from good- and poor-quality proteins was determined in balance experiments and by direct and indirect (body water) determination of $\mathrm{N}$ in rat carcasses. The results are now reported.

\section{EXPERIMENTAL}

Animals. Rats of our hooded Norwegian strain were used. They were weaned at 2 I days on to our normal stock diet (McKinlay, I95 I).

Experimental diets. The basal ' $\mathrm{N}$-free' diet had the percentage composition: rice starch 64, sugar I2, potato starch Io, margarine fat Io, salts (de Loureiro, I931) 4. The protein source to be tested replaced an equal weight of rice starch. To each $\mathrm{kg}$ of diet were added: thiamine $3.3 \mathrm{mg}$, riboflavine $5.5 \mathrm{mg}$, pyridoxine hydrochloride $3.3 \mathrm{mg}$, calcium pantothenate $\mathrm{I} .0 \mathrm{mg}$, folic acid $0.6 \mathrm{mg}$, biotin $0.6 \mathrm{mg}, p$-aminobenzoic acid I $1.0 \mathrm{mg}$, nicotinic acid I I. $\mathrm{mg}$, inositol I I0.0 $\mathrm{mg}$, choline hydrochloride I900 $\mathrm{mg}$, menaphthone (2-methyl-I, 4-naphthaquinone) $2 \cdot 2 \mathrm{mg}$, cyanocobalamin $20 \mu \mathrm{g}$. The diets were offered ad lib. In addition, 360 i.u. vitamin A, 26 i.u. vitamin D and $\mathrm{I} \cdot 4 \mathrm{mg} \alpha$-tocopheryl acetate were given separately by mouth, in arachis oil, to each rat at the beginning of an experiment and subsequently once a week in those experiments lasting for more than Io days.

Sources of protein tested. The following protein sources tested by Henry \& Toothill (r962) were used: vitamin-low casein (Genatosan Ltd), dried, defatted egg, soya-bean meal (sample 5), linseed meal, yeast and wheat gluten (Henry et al. 196I) and Agricultural Research Council samples of fish meal (FM6), meat meal (MM 20), soya-bean meal (SB I, 3, 5), cottonseed meal (CM I3, 19, 49), groundnut meal (GN I 1, r2, I8), sunflower-seed meal (SF I, 2, 3) and dried skim milk (SM 3, 7, 8, r3) (cf. Boyne, Carpenter \& Woodham, r96r). 
Determination of PER. Six litters of male rats, aged 23-26 days, were used in littermate comparisons in all experiments. Each rat was housed in a separate cage. The animals were given the experimental diets for 3 days to accustom them to the individual cages and to the change from the stock diet; subsequently records of weight increases and of diet intakes were kept for 4 weeks.

Determination of $B V$ and $T D$ of proteins by the balance-sheet method (Mitchell, 19234a; Mitchell \& Carman, 1926). Groups of twelve female rats aged 25-26 days were used in all tests. Details of the cages and experimental procedure are given elsewhere (Henry, Kon \& Watson, I937; Henry, Kon, Lea \& White, I947-8; Henry \& Kon, I956).

Determination of NPU by estimation of body water in rats. NPU (carcass) (Miller \& Bender, r955) and NPR (Bender \& Doell, 1957) were determined as described by Henry \& Toothill (1962).

PER determinations for comparison with $B V$ and NPU. The PER of the proteins listed on p. 126 was determined at an $8 \%$ level of protein intake in four experiments; vitaminlow casein was included as reference protein in each experiment.

Effect of level of protein intake. The PER and NPU (carcass) of whole-egg proteins, casein and wheat gluten were determined at 4, 8, 12, I6 and $20 \%$ levels of protein intake. $\mathrm{BV}$ and $\mathrm{TD}$ determinations were done at $4,8, \mathrm{I} 2$ and $\mathrm{I} 6 \%$ protein levels.

Effect of cortisone. The BV, TD and NPU (carcass) of casein, soya-bean meal, cottonseed meal $\left(\mathrm{CM}_{3} 3\right)$ and wheat gluten were determined at an $8 \%$ level of protein intake on normal rats and on litter-mates given daily a subcutaneous injection of $2.5 \mathrm{mg}$ cortisone acetate (Cortellan; Glaxo Research Ltd). The design of experiments to study the effect of cortisone on the BV and TD of proteins has been described by Henry et al. (196r). For NPU (carcass) determinations groups of rats were given both the ' $\mathrm{N}$-free' and the other diets with or without cortisone injections. No attempt was made to determine PER as cortisone administration usually causes weight losses.

Comparison of $N$ retention as determined by the balance-sheet method and by carcass analysis. Eight litters of four $3^{0}$-day-old female rats were used. One rat from each litter was killed at the beginning of the experiment and the carcass analysed for water and $\mathrm{N}$ as described by Henry \& Toothill (1962); these values were used to estimate the initial body $\mathrm{N}$ content of litter-mates given the experimental diets. The remaining three rats in each litter were given the $\mathrm{N}$-free diet, or diets in which casein, or wheat gluten supplemented with I \% DL-methionine, supplied $8 \%$ protein. These proteins were selected to be primarily deficient in methionine and lysine respectively. The rats were given the diets for Io days, urine and faeces being collected, and were then killed with coal gas and the carcasses analysed for water and $\mathrm{N}$ as above. Two groups of four rats were allotted to each diet as in the determination of NPU by estimation of body-water, so that duplicate values were obtained for NPU (carcass).

\section{RESULTS}

Table I gives PER values for twenty-three protein sources previously assayed by the balance-sheet and body-water methods (Henry \& Toothill, 1962). No result was obtained for a poor-quality meat meal (MM20) as three of the six rats lost 
weight during the experiment. The table includes values for PER, NPU (balance), i.e. $\mathrm{BV} \times \mathrm{TD} \div 100$, NPU (carcass) and NPR. All values are referred to casein $=100$ to facilitate the comparison between methods, as the units in which results are expressed vary with the method of assessment. It can be seen that, with minor exceptions, the four methods place these proteins in the same order. There was a high correlation between PER and NPU (balance), NPU (carcass) and NPR with $r=0.95,0.87$ and 0.88 respectively. The agreement between PER and the other methods was excellent for good-quality proteins but progressively worsened as the quality of poorer protein sources deteriorated. In general, good agreement was observed when rats grew at a rate greater than Io-12 $\mathrm{g} /$ week.

Table I. Mean protein efficiency ratio (PER), with its standard error, of twenty-three proteins or protein sources ( $p$. 126), PER, net protein utilization (NPU (balance) and NPU (carcass)) and net protein ratio (NPR) for these proteins when casein $=100$

\begin{tabular}{|c|c|c|c|c|c|}
\hline \multirow[b]{2}{*}{ Protein source } & \multirow[b]{2}{*}{ PER } & \multicolumn{4}{|c|}{ Casein $=100$} \\
\hline & & PER & $\begin{array}{c}\text { NPU } \\
\text { (balance) }\end{array}$ & $\begin{array}{c}\text { NPU } \\
\text { (carcass) }\end{array}$ & NPR \\
\hline Casein & $3.57 \pm 0.029$ & 100 & 100 & 100 & 100 \\
\hline FM6 & $3.90 \pm 0.058$ & 109 & 107 & 100 & 103 \\
\hline $\mathrm{SM}_{3} 3$ & $3.58 \pm 0.037$ & 100 & 100 & 105 & 109 \\
\hline $\mathrm{SM}_{7}$ & $3.53 \pm 0.08 \mathrm{I}$ & 99 & 97 & 103 & 108 \\
\hline $\mathrm{SM}_{3}$ & $3.49 \pm 0.079$ & 98 & 96 & 109 & 110 \\
\hline $\begin{array}{c}\text { Soya-bean meal }+2 \mathrm{~g} \\
\text { methionine } / \mathrm{r} 6 \mathrm{~g} \mathrm{~N}\end{array}$ & $3.47 \pm 0.068$ & 97 & 98 & 106 & 103 \\
\hline SM 8 & $3 \cdot 00 \pm 0 \cdot 110$ & 84 & 93 & 100 & 96 \\
\hline $\mathrm{SB}_{5}$ & $2.95 \pm 0.153$ & 83 & 82 & 83 & 9 I \\
\hline Soya-bean meal & $2 \cdot 8_{3} \pm 0.06_{4}$ & 79 & 84 & 85 & 86 \\
\hline SB I & $2.82 \pm 0.109$ & 79 & 85 & 84 & $9 \mathbf{1}$ \\
\hline $\mathrm{CM}_{49}$ & $2.71 \pm 0.150$ & 76 & 81 & 94 & 94 \\
\hline Dried brewer's yeast & $2.24 \pm 0.126$ & 63 & 82 & 78 & 79 \\
\hline $\mathrm{SF}_{2}$ & $2 \cdot 24 \pm 0.092$ & 63 & $8 I$ & 85 & 82 \\
\hline $\mathrm{SF}_{3}$ & $2 \cdot 20 \pm 0.052$ & 62 & 80 & $9 I$ & 88 \\
\hline $\mathrm{CM}_{19}$ & $2.13 \pm 0.059$ & 60 & 73 & 87 & 89 \\
\hline Linseed cake & $2.11 \pm 0.221$ & 59 & 76 & 95 & $9 \mathrm{I}$ \\
\hline GN 2 & $1 \cdot 70 \pm 0.120$ & 48 & 69 & 66 & 69 \\
\hline $\mathrm{SB}_{3}$ & $1 \cdot 66 \pm 0.109$ & 47 & 62 & 67 & 71 \\
\hline GN I 8 & $I .55 \pm 0.182$ & 43 & 65 & 60 & 61 \\
\hline$S_{I}$ & $\mathrm{I} \cdot 37 \pm 0.1 \times 9$ & 38 & 73 & $8 r$ & 80 \\
\hline GNII & I.I $5 \pm 0.099$ & 32 & 62 & 55 & 50 \\
\hline $\mathrm{CM}_{13}$ & $0.90 \pm 0.086$ & 25 & $5 \mathbf{I}$ & 71 & 74 \\
\hline Wheat gluten & $0.69 \pm 0.064$ & 19 & 65 & 64 & 71 \\
\hline
\end{tabular}

Fig. I shows the effect of level of protein intake on BV, TD, NPU (carcass), NPR and PER for whole-egg proteins, casein and wheat gluten. TD was clearly independent of the level of protein intake for the three proteins. The curves for BV and NPU (carcass) were roughly parallel. Egg and casein values showed no change when the protein level was increased from 4 to $8 \%$, but further increases in protein level caused a progressive decrease in these measurements, particularly in $\mathrm{BV}$, that was more marked for egg than for casein. Values for wheat gluten decreased progressively as the dietary protein level increased, the greatest difference being between 4 and $8 \%$. The two growth methods gave different responses. NPR decreased as dietary protein level 
increased for the three proteins; PER rose to a maximum at $8 \%$ for egg proteins and casein; for wheat gluten there was a slight progressive increase from the 8 to the $20 \%$ level, and no value was obtained at the $4 \%$ level as all animals lost weight.
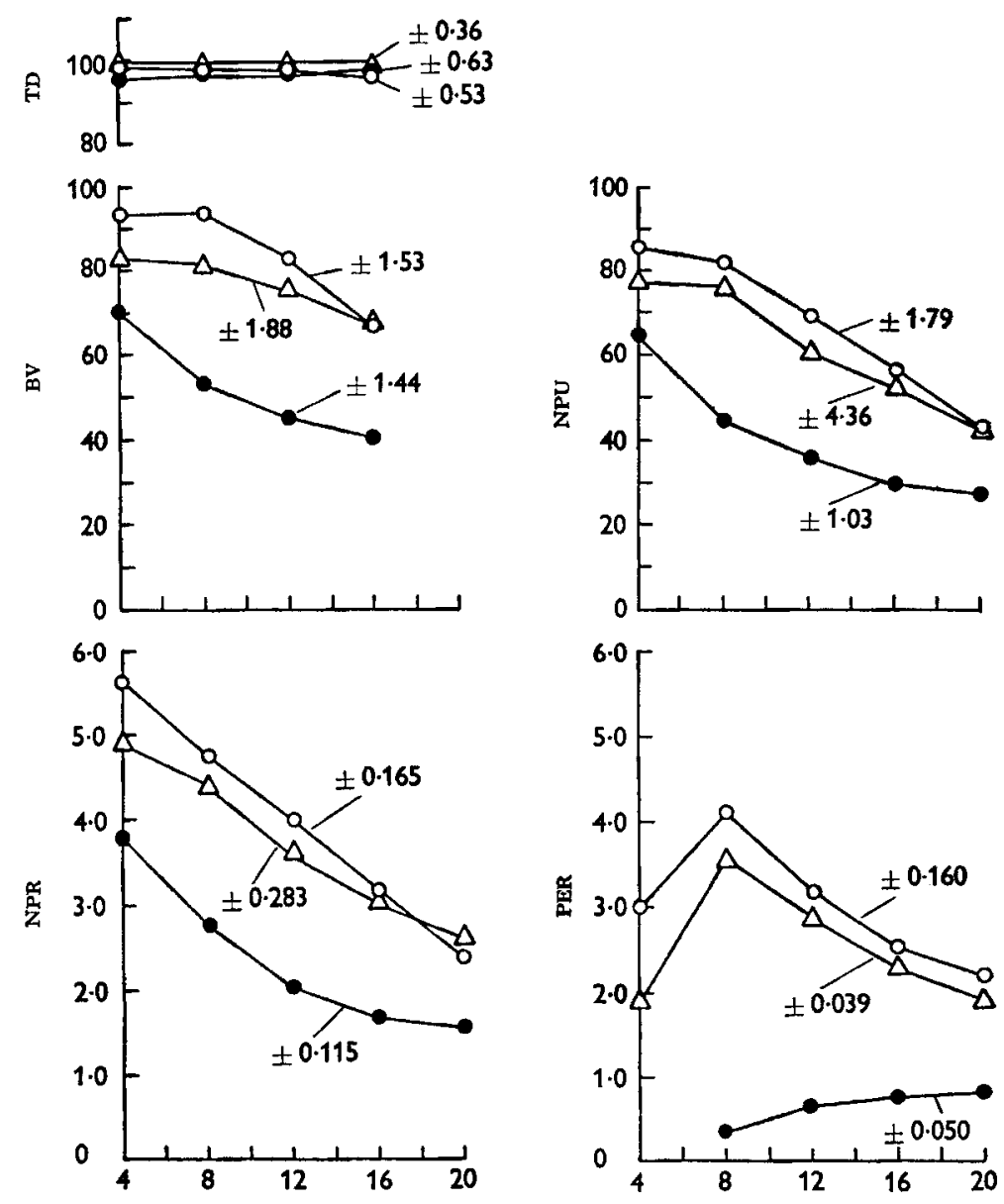

Protein in diet (\%)

Fig. I. Effect of level of protein intake on the biological value (BV), true digestibility (TD), net protein utilization by carcass analysis (NPU), net protein ratio (NPR) and protein efficiency ratio (PER) of whole-egg proteins $(\mathrm{O}-\mathrm{O})$, casein $(\triangle-\triangle)$ and wheat gluten $(-0)$. SEs of the plotted points are given on each curve.

Table 2 shows the effect of cortisone on the NPU (carcass), NPR and NPU (balance) of casein, soya-bean meal, cottonseed meal ( $\left.\mathrm{CM}_{3} 3\right)$ and wheat gluten. Values for all three measurements with these proteins were lowered by cortisone. The decreases were more marked for NPU (carcass) and NPR than for NPU (balance), particularly with wheat gluten for which the $6 \%$ loss in NPU (balance) was not statistically significant.

Table 3 shows that, compared with carcass- $N$ determination, the balance-sheet method overestimated both $\mathrm{N}$ lost by rats on a $\mathrm{N}$-free diet and $\mathrm{N}$ retained from diets supplying $8 \%$ protein as casein or wheat gluten supplemented with methionine. On 
all three diets $\mathrm{N}$ balances were reduced when carcass $\mathrm{N}$ was calculated from bodywater measurements. There were marked individual variations between rats, and analysis of variance showed that, for casein and wheat gluten, $\mathrm{N}$ retentions calculated from balance and carcass- $\mathrm{N}$ determinations did not differ significantly but that results

Table 2. Effect of cortisone on net protein utilization (NPU (balance) and NPU (carcass)) and net protein ratio (NPR) of casein, soya-bean meal, cottonseed meal and wheat gluten

Casein
Casein with cortisone
$\%$ decrease with cortisone
Soya-bean meal
Soya-bean meal with cortisone
$\%$ decrease with cortisone
Cottonseed meal
Cottonseed meal with cortisone
$\%$ decrease with cortisone
Wheat gluten
Wheat gluten with cortisone
$\%$ decrease with cortisone

$\begin{gathered}\text { NPU } \\ \text { (carcass) }\end{gathered}$
$74 \cdot 3$
$37 \cdot 7$
49
$57 \cdot 7$
$33 \cdot 2$
42
$47 \cdot 0$
$23 \cdot 2$
51
$44 \cdot 9$
$29 \cdot 3$
35

$\begin{array}{cc}\text { NPR } & \begin{array}{c}\text { NPU } \\ \text { (balance) }\end{array} \\ 4 \cdot 38 & 89 \cdot 8 \\ 2 \cdot 19 & 56 \cdot 1 \\ 5 I & 38 \\ 3 \cdot 34 & 67 \cdot 5 \\ 2 \cdot 17 & 47 \cdot 4 \\ 35 & 30 \\ 2 \cdot 77 & 48 \cdot 7 \\ I \cdot 20 & 36 \cdot 8 \\ 57 & 24 \\ 2 \cdot 72 & 55 \cdot 4 \\ I \cdot 85 & 52 \cdot 2 \\ 32 & 6\end{array}$

Table 3. Mean nitrogen retentions in 10 days, by groups of eight rats, from a $N$-free or $8 \%$ protein (casein or wheat-gluten supplemented with methionine) diet calculated from (I) analysis of food and excreta, (2) analysis of carcasses for $N$, (3) estimation of body $N$ from body-water determinations. Also net protein utilization (NPU) values for casein and wheat gluten calculated from these values

\begin{tabular}{|c|c|c|c|c|}
\hline Measurement & Method of calculation & $\begin{array}{c}\text { N-free } \\
\text { diet }\end{array}$ & $\begin{array}{c}\text { Casein } \\
\text { diet }\end{array}$ & $\begin{array}{c}\text { Wheat-gluten } \\
\text { diet }\end{array}$ \\
\hline $\begin{array}{l}\mathrm{N} \text { balance } \\
\text { (mg } N \text { retained) }\end{array}$ & $\begin{array}{l}\text { Analysis of food and excreta } \\
\text { Analysis of carcasses for } \mathrm{N} \\
\text { Analysis of carcasses for } \\
\text { water }\end{array}$ & $\begin{array}{l}-306 \cdot 1 \pm 8 \cdot 4 \\
-254 \cdot 5 \pm 24 \cdot 8 \\
-391 \cdot 3 \pm 25 \cdot 7\end{array}$ & $\begin{array}{r}289 \cdot 6 \pm 68 \cdot 0 \\
259 \cdot 1 \pm 90 \cdot 8 \\
93 \cdot 1 \pm 86 \cdot 7\end{array}$ & $\begin{array}{r}181 \cdot 5 \pm 27 \cdot 5 \\
123 \cdot 8 \pm 15 \cdot 7 \\
0 \cdot 0 \pm 41 \cdot 5\end{array}$ \\
\hline NPU & $\begin{array}{l}\text { Analysis of food and excreta } \\
\text { Analysis of carcasses for } \mathrm{N} \\
\text { Analysis of carcasses for } \\
\text { water }\end{array}$ & - & $\begin{array}{l}8 \mathrm{I} \cdot 8 \pm 2 \cdot 73 \\
63 \cdot 7 \\
(58 \cdot 7,68 \cdot 6) \\
60 \cdot 6 \\
(58 \cdot 2,62 \cdot 9)\end{array}$ & $\begin{array}{l}67 \cdot 5 \pm 2 \cdot 72 \\
49 \cdot 1 \\
(53 \cdot 8,44 \cdot 4) \\
50 \cdot 7 \\
(49 \cdot 0,52 \cdot 4)\end{array}$ \\
\hline
\end{tabular}

Values are mean values with their SE except when they are the mean of two values only, which are given in parentheses.

calculated indirectly from body water were significantly lower than either. With the $\mathrm{N}$-free diet, $\mathrm{N}$ losses calculated from balance values were intermediate between the two estimates from carcass analyses, and all differences were significant. The table includes NPU values calculated from the balance values and from carcass $\mathrm{N}$ determined directly or from the water content. The two values derived from carcass analysis agreed well but were lower than those derived from balance values. 


\section{DISCUSSION}

It is clear from Table $\mathrm{r}$ that, under standard experimental conditions, PER, NPU (balance), NPU (carcass) and NPR ranked the twenty-three proteins for which a PER value was obtained (see p. 127) in essentially the same order. Differences between methods were observed, however, when experimental conditions were changed (level of protein intake, Fig. I) or metabolic disturbances induced (cortisone treatment, Table 2). Chapman et al. (1959) studied six protein sources of different quality and observed a greater spread between good- and poor-quality proteins for PER than for NPU or NPR. They also found good reproducibility for the PER of casein. Our results confirm both of these findings. The PER value of casein given in Table I is the mean of four separate determinations of $3.63,3.52,3.5^{8}$ and 3.54 ; a further value of 3.52 was obtained in the experiment to study the effect of level of protein intake. These figures for casein are rather higher than those, determined at similar levels of intake, reported in the literature. An explanation probably lies in the observations of Keane, Smutko, Krieger \& Denton $(1962,1963)$ that higher PER values are obtained when diets are given moistened with water than when given dry. The latter appears to be the more general practice, but in this laboratory such diets are mixed to a thick paste with water to minimize scattering.

The results shown in Fig. I are in accord with the findings of other workers. Maximum values for PER have been reported at lower protein concentrations for goodthan for poor-quality proteins (Osborne et al. I9r9; Barnes, Maack, Knights \& Burr, I945; Yang, Clark \& Vail, 1959; Morrison \& Campbell, 1960a, $b$; Keane et al. 1962), although Jansen (1962) observed little change for casein and rolled oats as the dietary protein level was increased from 8 to $16 \%$. His results for wheat gluten supplemented with lysine were similar to those now reported for unsupplemented wheat gluten. TD was independent of the level of protein intake, as was also found by Forbes, Vaughan \& Yohe (1958) and by Munaver \& Harper (1959). Maximum Bvs are found at rather lower protein levels for poor- than for good-quality proteins (Mitchell, 1923$4 b$; Forbes et al. 1958; Rippon, 1959; Yang et al. 1959). The sharp decrease in the $\mathrm{BV}$ of wheat gluten, in which the first limiting amino acid is lysine, between the 4 and $8 \%$ protein levels is similar to that previously observed for a lysine-deficient sample of dried skim milk (Henry \& Kon, I957); the probable reasons for the finding were discussed by these authors. As would be expected, the curves for BV and NPU (carcass) were very similar; those for NPR resembled them rather than the curve for PER.

These observations that maximum BVs, but not PER, are usually found at an 8-10\% level of protein intake and are largely independent of protein quality may partly explain the greater spread in PER than in BV when determinations are made at a constant protein level (see Table I).

The differences between $\mathrm{N}$ retentions calculated from balance and carcass- $\mathrm{N}$ determinations (Table 3) can be attributed, at least in part, to inevitable analytical errors. Although not significant, the differences in $\mathrm{N}$ retention from casein and wheat gluten are in the direction observed by other workers (cf. Butterworth, 1962). They lend some support to the view that the discrepancy is largely caused by errors in the 
collection and analysis of excreta (Becker \& Harnisch, 1958; Müller, Wilmes \& Knappen, 1960; Butterworth, 1962; Chalupa \& Fisher, 1963). Such errors will be of less significance with a $\mathrm{N}$-free diet when smaller amounts of $\mathrm{N}$ are excreted.

Table 4. Mean values for nitrogen content of carcasses of rats, given a stock, nitrogenfree or $8 \%$ protein (casein or wheat gluten) diet, found by analysis or calculated from body-water determinations

\begin{tabular}{|c|c|c|c|c|c|}
\hline \multirow[b]{2}{*}{ Diet } & \multicolumn{2}{|c|}{ Rats } & \multicolumn{2}{|c|}{$\mathrm{N}$ in carcass } & \multirow{2}{*}{$\begin{array}{l}\text { Calculated } \\
\mathrm{N} / \text { found } \mathrm{N} \\
\quad(\%)\end{array}$} \\
\hline & $\begin{array}{l}\text { No. and } \\
\text { sex }\end{array}$ & $\begin{array}{c}\text { Age } \\
\text { (days) }\end{array}$ & $\begin{array}{c}\text { Found } \\
(\%)\end{array}$ & $\begin{array}{c}\text { Calculated } \\
(\%)\end{array}$ & \\
\hline $\begin{array}{l}\text { Stock } \\
\mathrm{N} \text {-free } \\
8 \% \text { casein } \\
8 \% \text { wheat gluten with methionine }\end{array}$ & $\begin{array}{l}8 \text { 우 } \\
8 \text { 우 } \\
8 \text { 우 } \\
8 \text { 우 }\end{array}$ & $\begin{array}{l}30 \\
40 \\
40 \\
40\end{array}$ & $\begin{array}{l}2 \cdot 65 \\
3 \cdot 06 \\
3 \cdot 03 \\
3 \cdot 00\end{array}$ & $\begin{array}{l}2 \cdot 63 \\
2 \cdot 86 \\
2 \cdot 85 \\
2 \cdot 85\end{array}$ & $\begin{array}{l}99 \\
93 \\
94 \\
95\end{array}$ \\
\hline $\begin{array}{l}\text { Stock* } \\
\text { N-free* } \\
8 \% \text { casein } *\end{array}$ & 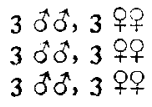 & $\begin{array}{l}3^{8} \\
3^{8} \\
3^{8}\end{array}$ & $\begin{array}{l}2 \cdot 71 \\
2 \cdot 81 \\
2 \cdot 83\end{array}$ & $\begin{array}{l}2 \cdot 72 \\
2 \cdot 67 \\
2 \cdot 62\end{array}$ & $\begin{array}{r}\text { roo } \\
95 \\
92\end{array}$ \\
\hline
\end{tabular}

Scrimshaw (1962) advises caution in the calculation of NPU (carcass) from bodywater measurements and points out that 'evidence is accumulating that the inherent assumption, i.e. that the ratio of gain in protein to gain in water is constant, does not hold good for all types of dietary protein', and Stucki \& Harper (1962) query the assumption 'that carcass $\mathrm{N}: \mathrm{H}_{2} \mathrm{O}$ ratios are constant at any given age regardless of the previous dietary treatment'. Some support for these doubts is evident from the values involving carcass analyses now presented. Table 4 gives the $\mathrm{N}$ content of litter-mate rats given our stock diet or the three experimental diets, determined directly or calculated from body-water measurements, together with earlier results (Henry \& Toothill, 1962). Although very few determinations were made, it is clear that the $\mathrm{N}: \mathrm{H}_{2} \mathrm{O}$ ratio determined with rats given our stock diet predicts accurately the $\mathrm{N}$ content of such rats but that it slightly, but consistently, underestimates $\mathrm{N}$ in rats given experimental diets. Standal ( $9_{96}$ ), on the other hand, found that the $\mathrm{N}$ content of the carcasses of rats given five experimental diets (one with no protein and four with $10 \%$ protein) was from I to $20 \%$ higher when calculated from water than from $\mathrm{N}$ analyses; he determined the relationship between water and $\mathrm{N}$ in the bodies of seventy-seven rats given diets containing six types of protein of varying quality. We have already pointed out (Henry \& Toothill, 1962) that a slight error is inherent in calculating $\mathrm{N}$ in the body from its water content, but concluded that the error would be constant for the $\mathrm{N}$-free and other experimental diets so that the NPU (carcass) values quoted in that paper would not be affected. This view is supported by the excellent agreement for both casein and wheat gluten when NPU (carcass) is determined by direct or indirect carcass- $\mathrm{N}$ measurement (Table 3 ).

Two further discrepancies between NPU (balance) and NPU (carcass) are evident in the tests with cortisone. In the first place the extent of the reduction in NPU (balance) varied with the quality of the protein, whereas the reduction in NPU (carcass) was 
similar for the four proteins tested. Secondly the reduction was more marked for NPU (carcass) than for NPU (balance). One cause of this finding is undoubtedly the error arising from the application of the $\mathrm{N}: \mathrm{H}_{2} \mathrm{O}$ conversion factor determined on normal rats to animals treated with cortisone: body water was reduced by such treatment but the change in body $\mathrm{N}$ may not have been proportional. The percentage loss in nutritive value of these proteins was very similar when measured as NPU (carcass) or NPR. This observation together with the close correlation for these quantities evident from Table I (cf. p. I28) support the views of Campbell (196I) and Njaa (1963) that NPU (carcass), calculated by the method of Miller \& Bender (1955), is the same as NPR, since the dominating factor in both terms is the difference in weight between groups of rats given a $\mathrm{N}$-free diet and the test protein. It may be concluded that, for a rapid routine assessment of protein quality, the simpler determination of NPR can replace that of NPU (carcass).

In general, and in spite of the greater amount of time and labour involved, balance methods are preferred to the simpler growth methods as they give more precise information (Njaa, 1963; (USA) National Research Council, 1963; Bigwood, 1964). Growth methods are, however, simpler than balance methods for the routine assessment of protein quality, and good correlation has been found between NPU (both balance and carcass) and PER (Block \& Mitchell, 1946-7; Henry et al. 1947-8; Bender, I956). PER has been criticized by Bender \& Doell (1957) because no value is obtained if the quality of the protein is too poor to permit growth; they consider that the inclusion of a control group given a $\mathrm{N}$-free diet in the determination of NPR overcomes this difficulty. However, workers have asked for further information on the significance and value of such a group (Campbell, Sabry \& Cowan, I963; (USA) National Research Council, 1963).

Campbell et al. (1963) conclude that the choice of method should primarily be determined on the basis of precision and reproducibility. Of the growth methods studied by them, they found that NPR values were no more stable than those for PER, whereas in this laboratory PER correlated with NPU (balance) rather better than did NPR (Table $\mathrm{r}$ and p. $\mathrm{r28}$ ). Good reproducibility for the PER of casein has been observed in Canada (Chapman et al. 1959) and in this laboratory (p. r3r), and Derse (r960) has reported good agreement between laboratories for three proteins of different quality when a standard procedure was adopted. On the other hand, discrepancies were observed between two laboratories when NPU (carcass) was determined from bodywater measurements (cf. Henry \& Toothill, 1962). There were similar discrepancies for NPR values calculated from the same data. It may be concluded that, at present, PER can be considered a more satisfactory growth method than NPR when used for the evaluation of proteins for growing children. The failure of the former to yield values for proteins of poor quality is not serious since, as Campbell (196r) has pointed out, a protein that will not support growth in the rat is unlikely to be of value for malnourished infants unless it can be shown to have supplementary properties. 


\section{SUMMARY}

I. The protein efficiency ratio (PER) was determined on rats, at an $8 \%$ level of protein intake, for twenty-three protein sources for which values for net protein utilization (NPU), determined from both balance data and carcass analysis, and net protein ratio (NPR) have already been reported (Henry \& Toothill, 1962).

2. PER values were highly correlated with those for NPU (balance), NPU (carcass) and NPR with $r=0.95,0.87$ and 0.88 respectively.

3. The biological value (BV), true digestibility (TD), PER, NPU (carcass) and NPR of whole-egg proteins, casein and wheat gluten were determined at $4-16 \%$ (BV and TD) or $4-20 \%$ (PER, NPU (carcass) and NPR) levels of protein intake.

4. Responses were similar for BV and NPU (carcass). Increasing the protein level from 4 to $8 \%$ had no effect for whole-egg proteins and casein but caused a sharp drop for wheat gluten; there was a continuous drop for all three proteins with further increases in protein concentration. TD was not affected by level of intake for the three proteins. PER increased between 4 and $8 \%$ and then fell continuously to the $20 \%$ level for egg proteins and casein; for wheat gluten there was a continuous slight rise from the 8 to the $20 \%$ level of intake; no. value was obtained at the $4 \%$ level. NPR dropped steadily from the 4 to the $20 \%$ level for all three proteins.

5. NPU, determined both from balance data and by carcass analysis, of casein, soya-bean meal, cottonseed meal and wheat gluten was reduced by a daily injection of $2.5 \mathrm{mg}$ cortisone acetate. The reduction in NPU (balance) decreased with protein quality from $38 \%$ for casein to $6 \%$ for wheat gluten; the reduction in NPU (carcass) was independent of protein quality and amounted to $35-50 \%$.

6. $\mathrm{N}$ retention from a ' $\mathrm{N}$-free' diet and from diets containing $8 \%$ protein as casein or wheat gluten was determined from balance data or from analysis of the carcasses for $\mathrm{N}$, determined directly or calculated from body-water values. NPU values for casein and wheat gluten were calculated from the three sets of data.

7. Compared with analysis of the carcasses for $\mathrm{N}$, the balance-sheet method overestimated both the $\mathrm{N}$ lost with the ' $\mathrm{N}$-free' diet and the $\mathrm{N}$ retained with casein and wheat gluten. The discrepancies were accentuated when $\mathrm{N}$ in the body was calculated from its water content. For both proteins, NPU (carcass) was independent of the method of determining body $\mathrm{N}$; the values were lower than for NPU (balance).

I am grateful for the assistance given by Miss M. V. Chapman in the care and feeding of the animals and by Miss H. Furneaux with the analytical work.

\section{REFERENCES}

Barnes, R. H., Maack, J. E., Knights, M. J. \& Burr, G. O. (1945). Cereal Chem. 22, 273.

Becker, M. \& Harnisch, S. (1958). Arch. Tierernähr. 8, 401.

Bender, A. E. (1956). Brit. F. Nutr. Io, 135.

Bender, A. E. \& Doell, B. H. (1957). Brit. F. Nutr. I1, 140.

Bigwood, E. J. (1964). Voeding, 25, I85.

Block, R. J. \& Mitchell, H. H. (1946-7). Nutr. Abstr. Rev. 16, 249.

Boyne, A. W., Carpenter, K. J. \& Woodham, A. A. (196r). F. Sci. Fd Agric. 12, 832.

Butterworth, M. H. (1962). F. Sci. Fd Agric. 13, 6. 
Campbell, J. A. (г96r). Methodology of Protein Evaluation: A Critical Appraisal of Methods for Evaluation of Protein in Foods. Nutrition Document R. Io/Add. 37 WHO/FAO/UNICEF-PAG (Mimeo).

Campbell, J. A., Sabry, Z. I. \& Cowan, J. W. (1963). Proc. int. Congr. Nutr. vi. Edinburgh, p. 489.

Chalupa, W. \& Fisher, H. (1963). F. Nutr. 81, 139.

Chapman, D. G., Castillo, R. \& Campbell, J. A. (1959). Canad. F. Biochem. Physiol. 37, 679.

de Loureiro, A. (г931). Arch. Pat., Lisboa, 3, 72.

Derse, P. H. (1960). Ұ. Ass. off. agric. Chem. 43, $3^{8}$.

Forbes, R. M., Vaughan, L. \& Yohe, M. (1958). F. Nutr. 64, 29 r.

Henry, K. M., Cormack, R. M. \& Kosterlitz, H. W. (1961). Brit. F. Nutr. I5, 199.

Henry, K. M. \& Kon, S. K. (1956). Brit. F. Nutr. 1o, 39.

Henry, K. M. \& Kon, S. K. (1957). Brit. F. Nutr. Ir, 305.

Henry, K. M., Kon, S. K., Lea, C. H. \& White, J. C. D. (1947-8). F. Dairy Res. r5, 292.

Henry, K. M., Kon, S. K. \& Watson, M. B. (1937). Milk and Nutrition. Part I, p. 37. Reading: National Institute for Rescarch in Dairying.

Henry, K. M. \& Toothill, J. (1962). Brit. F. Nutr, 16, 125.

Jansen, G. R. (1962). F. Nutr. 78, 23 I.

Keane, K. W., Smutko, C. J., Krieger, C. H. \& Denton, A. E. (1962). F. Nutr. 77, I8.

Keane, K. W., Smutko, C. J., Krieger, C. H. \& Denton, A. E. (I963). F. Nutr. 8r, 87.

McKinlay, H. G. (195I). F. Anim. Tech. Ass. 2, no. 2, p. 2.

Miller, D. S. \& Bender, A. E. (1955). Brit. F. Nutr. 9, 382.

Mitchell, H. H. $(1923-4 a)$. F. biol. Chem. 58, 873 .

Mitchell, H. H. (1923-4b). F. biol. Chem. 58, 905 .

Mitchell, H. H. \& Carman, G. G. (1926). F. biol. Chem. 68, 183

Morrison, A. B. \& Campbell, J. A. (1960a). F. Nutr. 7o, г12.

Morrison, A. B. \& Campbell, J. A. (1960b). Canad. F. Biochem. Physiol. 38, 467.

Müller, R., Wilmes, G. \& Knappen, F. (1960). Arch. Tierernähr. ro, 326.

Munaver, S. M. \& Harper, A. E. (1959). F. Nutr. 69, 58.

National Research Council (1963). Publ. nat. Res. Coun., Wash., no. I 100.

Njaa, I. R. (1963). FiskDir. Skr. Teknol. Undersøk. 4, no. 5.

Osborne, T. B., Mendel, L. B. \& Ferry, E. L. (1919). F. biol. Chem. 37, 223.

Rippon, W. P. (1959). Brit. F. Nutr. 13, 243.

Scrimshaw, N. S. (1962). Food Tech. 16, no. 5, p. 26

Standal, B. R. (1963). F. Nutr. 81, 279.

Stucki, W. P. \& Harper, A. E. (1962). Ұ. Nutr. 78, 278.

Yang, S. P., Clark, G. E. \& Vail, G. E. (1959). Ұ. Amer. diet. Ass. 35, I 25 I. 